Article

\title{
Employee Representatives and a Good Working Life: Achieving Social and Communicative Sustainability for HRM
}

\author{
Isabell Koinig $1, *(\mathbb{D})$ and Franzisca Weder ${ }^{2}$ \\ 1 Department of Media and Communication Studies, University of Klagenfurt, 9020 Klagenfurt, Austria \\ 2 School of Communication and Arts, University of Queensland, Brisbane, QLD 4072, Australia; \\ f.weder@uq.edu.au \\ * Correspondence: isabelle.koinig@aau.at; Tel.: +43-463-2700-1814
}

Citation: Koinig, I.; Weder, F.

Employee Representatives and a Good Working Life: Achieving Social and Communicative Sustainability for HRM. Sustainability 2021, 13, 7537. https://doi.org/10.3390/su13147537

Academic Editor: Tamás Bányai

Received: 31 May 2021

Accepted: 2 July 2021

Published: 6 July 2021

Publisher's Note: MDPI stays neutral with regard to jurisdictional claims in published maps and institutional affiliations.

Copyright: (c) 2021 by the authors. Licensee MDPI, Basel, Switzerland. This article is an open access article distributed under the terms and conditions of the Creative Commons Attribution (CC BY) license (https:// creativecommons.org/licenses/by/ $4.0 /)$.

\begin{abstract}
This article examines the role of employee representatives, who support HRM in positioning itself and the organization as "socially responsible". Based on a constructivist understanding of organizational communication, employee representatives are examined as previously unrecognized entities that are responsible — and also essential—for guaranteeing a good working life, which also originates through communication. The article provides an overview of existing studies on employee representatives and their positions in companies and tries to bridge the gaps among organizational communication, CSR communication, and management theory by redesigning the role of employee representatives-who have received limited academic attention to date-as communicators. The insights from an international comparative study confirm that employee representatives perceive themselves not only as a "grief box" or "control body" of management, but also as a responsible agent and "medium" for the realization of social and communicative sustainability. This not only opens up new research perspectives, but also highlights the need to conceptually deal and theoretically discuss employee representatives and their roles in internal communication processes from the perspectives of organizational communication, HRM, CSR, and sustainability.
\end{abstract}

Keywords: good working life; employee representatives; corporate responsibility; role models; HRM; SRHRM

\section{Introduction}

It has always been the task of companies to set and meet basic human needs. Thus, organizations contribute to social welfare and individual wellbeing by serving as enablers of the "good life" — both socially and economically, especially in relation to the corporate environment. As a normative goal, the good life at work has been included in the UN's Sustainable Development Agenda. In detail, Goal 8 is concerned with ensuring decent work and economic growth, with Targets 8.3 and 8.8 highlighting the need to promote "decent job conditions" and "safe and secure working environments for all workers", respectively [1]. In recognizing employees as core organizational assets-a reasoning that is in line with a resource-based organizational view [2] -investing in employee wellbeing is closely linked to organizational CSR activities, which are used to enhance corporate reputation, build legitimacy, and increase organizational performance in the long run [3,4]. As CSR is concerned with contributing to social welfare, it also encompasses an organization's contribution to employee welfare and wellbeing [5].

In recent years, the contribution of human resource management (HRM) to organizational performance has not only been increasingly recognized, but has also received significant academic attention [6-10]. Changes in the orientation of HRM are, first and foremost, conditioned by a paradigm shift that stresses the necessity of investing in competitiveness (and skilled employees) instead of boosting productivity: "People were perceived as proactive, endowed with intelligence, knowledge, skills, and differentiated abilities, 
which should be identified, developed, and enhanced in terms of organizational performance and individual commitment" [10]. Since human resources are hard to copy, they constitute an organization's rarest and most valuable resource [11] and are part of the organization's sustainability story [12].

HRM is grounded in the assumption that employees are paramount to organizational success; therefore, they need to be invested in and appropriately managed [13]; in consequence, employees' innate needs must be met, including job satisfaction and welfare [14]. Following Tyson and Fell [15], human resource management covers four areas of action: (1) the preservation of organizational values, (2) a contribution to organizational sustainability, (3) the securing and establishment of organizational boundaries, and (4) the management of change.

Against the background of increasing CSR activities, human resource management has moved towards a "socially responsible human resource management" (SRHRM; [5]). Expanding stakeholder theory [16,17], which perceives employees to be crucial to organizational success, SRHRM is conceptualized as "corporate social responsibility (CSR) directed at employees" [18]. While it is made up of three pillars—namely, legal compliance HRM, general CSR compliance, and employee-oriented HRM — the last aspect is of particular relevance to the study at hand. Employee-oriented HRM is concerned with satisfying employees' motivational skills and self-actualization [19] and, as such, is directly linked to the concept of the good working life. To realize its full potential, SRHRM must be supported by appropriate communication systems [11] — even if organizational, strategic, or public communication are not currently captured by a specific Sustainable Development Goal [1].

The specific challenge for companies lies in finding a balance between the economically sensible, socially "good" notions of sustainability and the cultural and ecological notions of sustainability, as well as the plurality of issues and voices talking about those issues within and outside of an organization. Without doubt, employee wellbeing and, as such, the good life, are in the best interest of employers [20]—they must be communicatively created as core values. It is through HRM that organizations can create the common sense about a "good life at work" and implement SRHRM [21], in which communication processes and internal communication structures play a major role [17]. In countries with established labor regulations, even unions or employee representatives assist organizations in creating good working environments [14]. Employee representatives are defined as appointed individuals acting on behalf of an employee "to represent them for the purpose of negotiating with management on issues such as wages, hours, benefits, and working conditions" [22].

While the notion of the good life has evolved over time, it might be threatened by geopolitical, health (pandemic), or economic events (financial crisis); moreover, there are distinct conceptualizations of the good life in different parts of the world due to varying sociopolitical and cultural circumstances [23-25].

This article examines the role of employee representatives, who support HRM in positioning itself and the organization as "socially responsible". Based on a constructivist understanding of organizational communication, employee representatives are examined as previously unrecognized entities that are responsible — and essential—for guaranteeing a good working life, which also originates through communication. This article provides an overview of existing studies on employee representatives and their positions in companies and tries to bridge the gaps among organizational communication, CSR communication, and management theory by redesigning the role of employee representatives-who have received limited academic attention to date-as communicators.

In this paper, we bridge the existing SRHRM literature with the perspective of organizational communication and introduce the employee representative as a holder of moral agency and communicative responsibility. We refer to data from an international comparative research project on both the potentials of and limits to the realization of a "good life" and the associated ethical principles in organizations. Employee representatives hold the 
potential to open up a communicative scope for the realization of a good working life. This also harbors a significant amount of potential for future organizational communication, CSR, and sustainability communication research.

\section{Literature Review}

\subsection{On the Increasing Relevance of Employee Representatives}

Several concepts have been introduced for the investigation of employees' working experiences. For instance, the quality of work life (QWL; [26]) is used to describe employees' broader experiences of the workplace environment. It requires organizations to recognize that employees do have a life outside of work, evoking employers to optimize working conditions and contextual factors in order to improve employees' experiences of and in the workplace [27]. These arguments are in line with the Psychology of Working Theory, according to which decent work presents an essential aspect of individuals' lives; it further accounts for the influence of work on individual wellbeing (and, as such, the good life; [28,29]). Decent work describes individuals' aspirations in their working lives by further guaranteeing employee rights, access to collective bargaining, and representation [30].

Management styles also account for representation to varying degrees. Out of Likert's four archetypical management systems, two systems account for employee participation and optimized experiences: the consultative system (which is based on a more paternalistic leadership style) and the participative system [31]. It is particularly the latter that utilizes employee participation and involvement and "makes maximum use of participative methods, engaging people lower down the organization in decision making" [32]. Individual participation is enabled by so-called linking pins, described as individuals who occupy a prominent role in multiple groups and engage in communicative exchanges when needed [32,33]. From a communication perspective, employee representatives match the characteristics of linking pins (as described by Likert and Likert [32]), as they are parts of multiple groups, occupy a position of status, communicate both upwards and downwards within the organization, adapt their communication styles to the requirements of the respective group, work out solutions that are meant to satisfy all parties, and ensure that each party fulfills their responsibilities. As such, employee representatives are "persons who hold overlapping memberships" that link different groups into a "cohesive team" [34].

In recent years, organizations have started to pay attention to employees' personal situations. Organizational environments have prioritized performance, quality, and efficiency in the past; at present, the expanded organizational environment is one in which employee health and wellbeing are also considered, together with social and personal values. These redefined values also fuel organizational communication processes towards the good life at work.

As part of SRHRM, employers "take the present and future wellbeing and performance of their employees into account" [35]. For some years, work has been listed amongst the top three sources of stress [36] - a concerning tendency that is confirmed by numerous surveys and statistics. In most instances, work-related stress was found to have effects on individuals' health, leading to sleep deprivation or mental health issues, amongst others $[37,38]$, and it also negatively affects employees' private lives [39,40]. Working groups dedicated towards employee health and wellbeing allow for a company-wide integration, and usually feature employee representatives who address employees' interests [41-43]. Employee representatives accept responsibility for the good working life, while also constituting its target group. As such, they serve as organizational role models [44].

As mentioned before, the good life at work is increasingly discussed as part of CSR research [45-48] and has also been found in sustainability communication [49-51]. In this context, sustainability is understood as a normative framework or a moral compass $[50,52,53]$ for individual and organizational action.

In this paper, we do more than simply bridging the existing literature from a management and organizational perspective (SRHRM) with communication theories and the concept of sustainability communication [49,54-57]; we go beyond strategic communi- 
cation or targeted communication management in favor of a constructivist approach to communication [58-60], which postulates that communicators within a certain organizational structure (e.g., employee representatives) occupy a specific communicative role in the sense of building trust and establishing culture and meaning within organizations. From a constructivist perspective, every conversation is part of larger meaning-making and value-building processes. Thus, our reasoning begins with the assumption that employee representatives are assigned a form of communicative responsibility for ensuring a good working life-an aspect that is absent from research to date. Even if employee representatives are assumed to occupy a central role in organizations in general, their role in organizational communication processes and, particularly, in processes of social transformation and change is rather under-researched. By introducing sustainability as a normative framework for social practices within organizations, the significance of employee representatives in processes of social, moral, and organizational change becomes obvious. In the following, we discuss the designated role and position of employee representatives as outlined in work councils' frameworks and related regulations in different cultural contexts before complementing this understanding with insights from an empirical study.

\subsection{Employee Representatives and Works Councils-An International Comparison}

In the age of globalization and rapid technological changes, companies are challenged to keep employees with their company in the long run; increasingly, they have started to integrate employees' interests and to take responsibility on both the ecological and social levels in order to reduce turnover rates [46,61,62]. Specifically in Europe, companies are not solely responsible for their employees' wellbeing, but are supported in this endeavor by unions/works councils and employee representatives. In the following, four models are presented, in which a good working life is institutionalized to varying degrees either in the form of a union or is enabled by corresponding organizational structures.

Looking at the European market, (1) the German model, (2) the French model, (3) the Anglo-Saxon model, and (4) the Scandinavian model can be distinguished [22]. Apart from Germany, Austria and Belgium also utilize the German model, in which employees are given the chance to actively participate in corporate decision making due to legal regulations that increase the relevance of employee representatives as "intermediary speakerphone[s]" when compared to works councils [63]. In the French model, which is applied in Belgium and Luxemburg, as well as the Mediterranean countries of the EU, the nomination of employee representatives is required by law, but they are only granted minimal rights, and occupy information and consultation roles [22]. This model significantly differs from the Anglo-Saxon model, which is characteristic of the UK and Ireland, in which employees can only turn to union representatives in case of need. Employee representation is not addressed by law altogether and is left to corporations [64]. The Scandinavian model presents a mix of both the German and Anglo-Saxon models; there, employee representatives are not backed up by any legal regulations. The only exception are companies with more than 150 employees, which have the right to appoint employees as representatives at the board level, where they work closely with union representatives [63].

In all four models, an employee representative is part of a "system in a company for managers to take into account employees' opinions, wishes, etc. in managing the company" [65]. As such, employee representatives can be considered an extension of HRM [66]. All models integrate employees' concerns to varying degrees, but regulate their level of influence. Organizational structures build an enabling framework that, nonetheless, limits employee representatives' scopes of action, as institutionalization is absent from most models. In the following, previous studies dealing with employee representatives and their roles within organizations will be reviewed.

\subsection{Academic Debates about and Research on Employee Representatives}

Building on the forms of organizational participation described above, the involvement of employees, and the roles of interest groups in supporting the representation of 
employees' interests, a plethora of studies has thematized the role or functions of employee representatives in different countries within and outside of Europe, e.g., in Croatia [67], Denmark [68,69], France [70,71], Germany [72,73], Norway [74], and Spain [75]. In addition, the roles and internal functions of works councils have received academic attention (e.g., [76]).

Works councils are often associated with corporate governance measures. Corporate governance encompasses the management of an organization for the goodwill of all entrepreneurial stakeholders [77] and is strongly associated with CSR. In this context, employees are given a "voice", which is usually delegated to works councils, who serve as the employees' mouthpiece [66,78,79]. The appointment of a representative group that serves employees' interests increases the participation of employees in entrepreneurial decisions, thus positively influencing the relationship between employers and employees [80,81]. While several studies reported positive results [82-84], others were more critical $[68,85,86]$. Particular attention was given to the fact that employers' and employees' interests often contradict one another; for this reason, the questions of conflicts, conflict resolution strategies [86], and the roles of works councils in the context of conflict management have been repeatedly thematized [87].

Other studies on works councils dealt with a variety of topics, including employee representatives' roles in negotiating pension claims $[88,89]$ or engaging in social dialogues within the organization [90], their contributions to entrepreneurial success [91,92], the historical development of the works council culture in Europe and in individual European countries [93], the relevance of works councils to entrepreneurial innovation [94], and the (stress-related) burdens faced by works councils $[95,96]$, which are rather frequently caused by role conflicts [86,97].

Generally, employee selection, personnel administration, and the strategic management of employees are tasks of HRM [10]. HR managers are often referred to as strategic partners or change agents $[98,99]$. Although human resource managers support organizations in their sustainable development [100], in some countries, national (or nationally binding) labor agreements and trade unions assist them in creating organizational success [14]. In these countries, a works council is part of the structural organization whose task is to consider employees' wishes and needs in entrepreneurial decisions. To be able to fulfill this task, works councils must have timely access to all relevant information; by law, they have the right to be involved in financial and personnel decisions [92,101]. Nerdinger and Wilke [102,103] even claim that this involvement is of utmost importance, since employees' interests (e.g., job security and high-quality working conditions) and organizational interests (e.g., innovation) are mutually dependent [104]. Hence, it seems plausible to give employees an opportunity to participate, e.g., by joining a works council [94].

In the broadest sense, the tasks of works councils can be summarized by the following three key terms: consultation, participation, and negotiation [105]. In a narrower sense, works councils are (1) consulted as soon as disputes arise between different parties (e.g., employees and employers), (2) committed to maintaining current and future relationships, and (3) involved in resolving conflicts. Works councils work with employers "in a spirit of mutual trust [and] for the good of the employees and the establishment" [106].

From an institutional perspective, employee representatives' tasks involve safeguarding a good working life [107]. In the area of organizational ethics and organizational communication, however, both responsibility and the good life are conceptualized in a different way. Freeman and Medoff [108] first discussed the concept of the employee's voice in relation to unions, stating that an employee's involvement can have positive effects on an organization's return on investments, as well as on corporate culture [109-112].

The following roles of works councils are commonly discussed in the literature: "employee voice" [113], "representatives and bargainers" [114], "savers of workplace law" [115], "safeguards of labor interests" [116], "attendants of organizational change" [117], and "innovators" [118]. In German-speaking countries, works councils are primarily seen as a "protective power for the workforce" or a "link between workforce and management" (as 
part of the so-called co-management; [119]). As "competent crisis managers, agents of change, and promoters for change" [120]( see also [121,122]), employee representatives are called upon to ensure that legal requirements and entrepreneurial interests-especially those that affect employees-are not violated.

While communication is described as one of the five core tasks of works councils [123], this assumption will be challenged in the present contribution. Input will be drawn from a constructivist perspective on organizational communication (CCO; [58]). From our perspective, the "institutionalized voice" as a static concept of communication must be complemented by a more critical perspective that also encompasses interactions, discourses, and communication processes in organizations that "reproduces" an organization itself (see Figure 1).

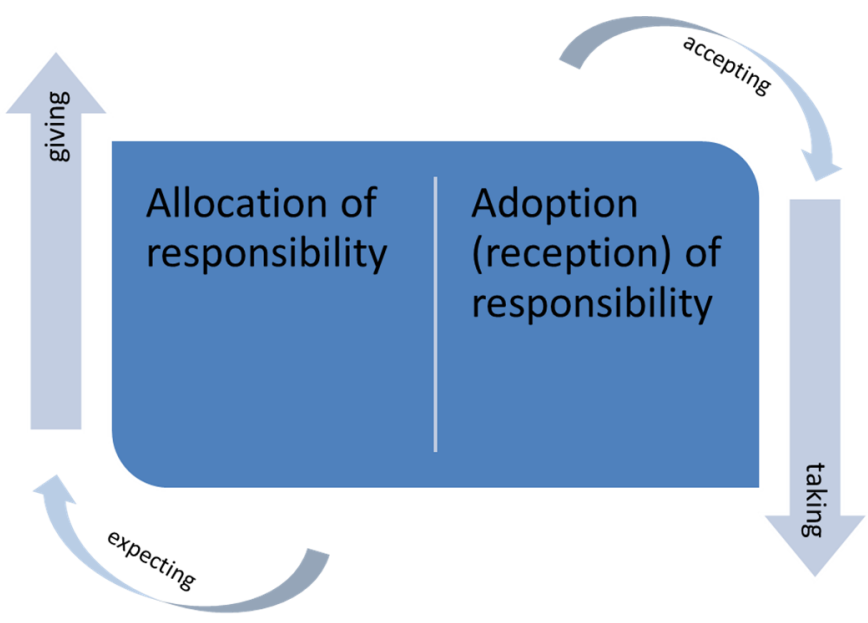

Figure 1. Dynamics of organizational responsibility (authors' own illustration).

The existing literature on works councils addresses neither attributions of responsibility nor the communicative construction of a good working life. Although works councils are fixed entities and "institutionalized communication hubs" in companies [124], the communication of works councils has, so far, been rather top-down, formal, and indirect. Works councils' role attributions are also related to the respective market situation and national legal framework; while liberal markets hardly offer any space for alternative forms of participation (such as advocacy groups) and are regulated by market mechanisms, coordinated markets allow for participation in the form of works councils and employee representatives $[125,126]$. This assumption will also be challenged by the study presented herein.

\section{Employee Representatives and the "Good Life" at Work}

The new conceptualization of works councils as moral agents-as "agents of responsibility" with a corresponding communicative responsibility [17]—is based on an understanding of organizational communication as a process of meaning creation. From an institutional perspective, the role of works councils includes ensuring employees' good working lives, and is seen as a legal obligation, particularly in the German model. In detail, the legal mandate of employee representatives includes "protecting and promoting the economic, social, health, and cultural interests of employees in the company" (Article 38 of the Labor Constitution; quoted in [125]).

Dyne et al. [110] discussed the differences between the absence and the deliberate restraint of employee participation in the company. "The key feature that differentiates silence and voice is not the presence of absence of speaking up, but the employee's motivation to withhold versus express ideas, information, and opinions about work-related improvements" [110]. Other authors offer similar rationales, and it almost seems as if companies are called upon to ensure an institutionalized form of employee participa- 
tion $[126,127]$. For this reason, it makes sense to supplement the "static" view of employee participation with a more critical discussion - one that also considers interactions, discourses, and communication processes and is based on the assumption that organizations can only be created through communicative actions [128].

As responsibility is not a moment of certainty [129] and is based on fluid role perceptions (someone is in charge, but it is irrelevant who this is and which role this person holds), moral agency must be re-conceptualized as well. Moral agency is realized through different roles or in communicative interactions between complementary roles. It can be seen as a "normative competence" that involves the ability to grasp and apply moral reasoning and that governs one's behavior in the light of such reason [130]. Following the communicative constitution of organizations (CCO; [58]), communication is seen as socially constructed, as the "molar concept" of every kind of organization [131,132]. On the one hand, we conceptualize moral agency as something that is communicatively constructed and realized in interactions and through communication; on the other hand, moral agency is directed towards improving the lives of others [133] and, as such, also relates to employee's working lives. This is the case since individual action, interaction, or acts of communication affect the organization as a whole [132] and vice versa; every organizational member can be held accountable for what they say and for every act of communication that they engage in (see Figure 2).

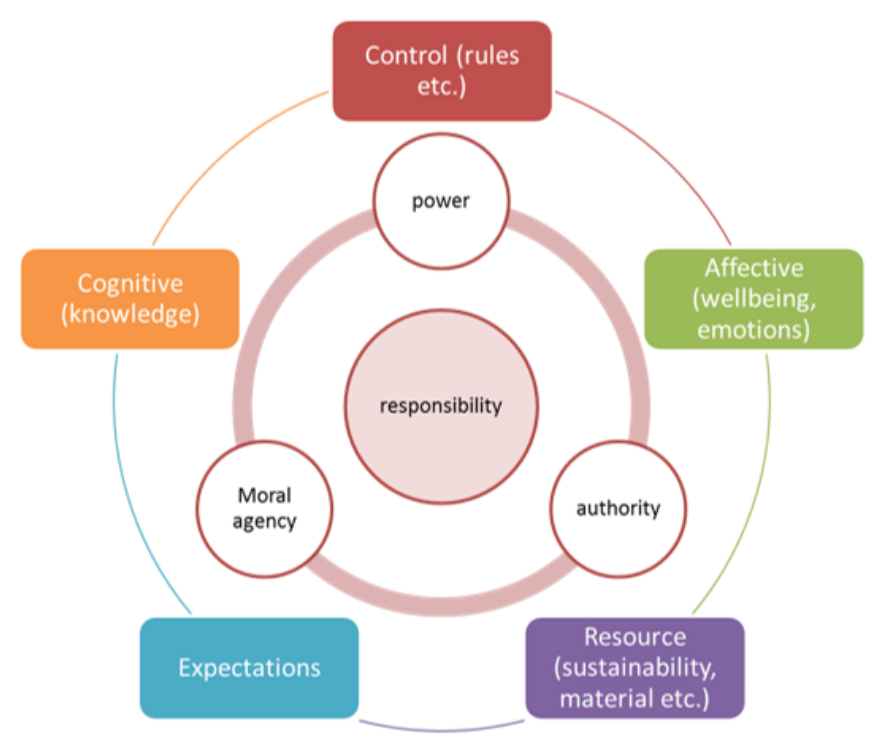

Figure 2. Dimensions of responsibility (authors' own illustration).

This last argument corresponds with the philosophical tradition beyond determinism and causal responsibilities, stipulating that "responsible agents are not those agents whose actions are uncaused, but rather those agents who possess certain competences or capacities" [134]. This would imply that if these agents are institutionalized or accounted for by law, they can realize their agentic roles more easily (through interactions and communicative acts). We thus assume that in the case of less structure or missing legal frameworks, less attention is given to the constructive potential of communication in creating a common understanding and realization of a good working life in organizations, where it is reproduced through organizational communication, institutionalized to varying degrees, and expressed through communicative actions [132,135]. In the following, the roles of employee representatives, as well as their communicative roles in guaranteeing and safeguarding a good working life will be discussed in more detail. Moreover, their role in enabling (strategic) organizational efforts to create a healthy and productive work environment in which individual health and wellbeing can thrive is scrutinized [136-139]. 


\section{Empirical Study: Communicative Freedom of Action for Employee Representatives 4.1. Sample}

Qualitative interviews with employee representatives or members of the works councils in companies of varying sizes were conducted in seven countries. The sample included 57 employee representatives from Austria, Germany, Slovenia, Switzerland, Finland, the United States, and Great Britain. In detail, the convenience sample consisted of 30 Austrian, 7 German, 5 British, 5 US American, 4 Slovenian, 3 Swiss, and 3 Finnish employee representatives. The first two countries, which are representative of the German model, were chosen because both Germany and Austria have a long history of strong labor unions, employee organizations, and representatives, while this is not the case in the UK or the US. Finland, which is a representative of the Scandinavian model, is also characterized by a high level of unionization, while in the case of Slovenia and Switzerland, employee representatives have only limited rights. Both countries most closely resemble the French model. The employee's elaborations and explanations form the core of the study corpus [140]. The employee representatives surveyed mostly worked in medium-sized to large companies, which — to varying degrees—-had established works councils and unions.

\subsection{Method}

A qualitative research approach was chosen, as instead of confirming existing research findings, the focus of the chosen method was to obtain new insights into the research area [141]. Semi-structured interviews were conducted by trained coders, who received training from the researchers. Interviews were used to give the interview partners freedom to elaborate on selected aspects [142-144]. The interviews were conducted either in person or via Skype and in each employee representative's native language. For the paper, suitable interview passages were translated into English. The semi-structured interview questions can be found in the Appendix A.

In detail, the research project intended to uncover the extent to which employee representatives could influence the process of securing a good working life by exploring (a) the roles and labels ascribed to employee representatives, (b) their tasks, (c) the role of communication in allocating and taking responsibility, (d) definitions of a good working life, and (e) the potential for realizing a good life at work. Ultimately, our goal was to work out differences between highly institutionalized forms of moral agency and less structured and institutionalized forms of moral agency (i.e., as illustrated by the previously introduced employee representation models).

Interviews were conducted from January to April 2014 and from August to November 2016. Each interview was audiotaped and fully transcribed afterwards. Interview material was analyzed via content analysis, as proposed by Mayring [145-147]. According to Mayring [145], the advantage of a qualitative content analysis is "systematically analyzing texts by processing the material step by step using category systems that have been developed based on theory". In the process of the analysis, the material was divided into units and summarized to answer the previously introduced research questions. In the following, the study's core results will be presented.

\section{Discussion of Results}

\subsection{Roles and Labels Ascribed to Employee Representatives}

Regarding their self-perception, the present study found support for various roles that employee representatives are claimed to occupy, with most of them being almost identical to the ones identified in the literature (see [109-119]). The terms most cited were mediator (Am [the abbreviations must be read as follows: The upper-case letter(s) refer(s) to the country (A for Austria, G for Germany, US for United States, GB for Great Britain, F for Finland, $\mathrm{S}$ for Slovenia, and $\mathrm{CH}$ for Switzerland), while the lower-case letter indicates the sex of the interviewee ( $\mathrm{m}$ for male and $\mathrm{f}$ for female)]), connecting piece (Am), spokesperson $(\mathrm{Am})$, internal and external contact person $(\mathrm{Am})$, single point of contact $(\mathrm{Am})$, partner to both the executive board and the management (Gf), and cook general (Gf). 


\subsection{Employee Representatives' Tasks}

Similarly to the employee representatives' vast labels, their tasks also widely varied in focus and they were, at least in part, concerned with safeguarding a good working life. In addition to representing employees' interests to the executive board and owners (Am) and working closely together with labor and trade unions and the official representation of employees $(\mathrm{Am})$, their duties also involve protecting employees, an enterprise's most valuable asset (Am), guaranteeing equal opportunities for everyone and transparency within a company (Am), creating a WIN-WIN situation for all parties (Af), bringing legal-and binding-statutory provisions to managers' attention (Am), promoting fairness by advancing employee interests for the common good (Gf), and translating complex matters into simple pieces of information for employees (Af).

However, employee representatives' work is sometimes challenged, as they must act on behalf of all groups of interest and not put some interests ahead of others (Af). One representative even claimed that you must be positive about your work and believe that you can change something (Am).

\subsection{The Role of Communication in Allocating and Taking Responsibility}

To become actively involved, employee representatives must be made aware of existing problems, rendering communication key. As everything stands and falls with communication (Am), communication is the most important job requirement (GBm). By communication, employee representatives mean permanently staying in touch with the parties involved (Am), permanent communication, direct/personal communication, and not problem-focused, event-focused communication (Af), and, as such, regular communication, without cause (Af). Communication also comprises informal communication during coffee breaks or small talk (Af), where employee representatives are given the chance to learn the most about employees' concerns (Af). As a Swiss employee representative put it: Through communication, a lot can be prevented, but also a lot can be achieved (CHm). Only then can employee representatives inform the CEO about problems and ideas (Gf).

To inform employees about new developments and regulations, employee representatives rely on internal communication channels, such as the Intranet, newsletters (Sf, Gf), or bulletin boards (Am). Both Austrian and German representatives agreed that work agreements or legal guidelines are required so that employees can derive a claim from them and that they are communicated and explained to everyone in such a way so everyone can make use of such regulations (Af). Nonetheless, there was agreement across employee representatives of all countries that communication needs to flow in both directions-top-down and bottom-up (Sf).

In terms of works councils' roles within the organization, communication is primarily limited to providing information, as emphasized in the theoretical section (see $[63,110]$ ).

\subsection{Definitions of a Good Working Life}

Communication is also central to establishing concepts of a good working life. From the employee representatives' viewpoint, notions of a good working life encompass working together with each other (Af), employees' self-realization (Am), getting along well with colleagues and superiors, and mutual respect (Gf). A good life at work also affects employees' personal spheres, where it finds expression in the balance between work and personal life (USf, Fm). As such, it concerns the ability to live at a desired personal comfort without financial, social, psychological, or other kinds of complications (USm), allowing people to juggle a successful career with having a healthy and good friendship or relationship (GBf).

One Swiss representative highlighted that a good life requires commitment on the part of employers: Eventually, a good life can be communicated based on examples. If the top management exemplifies a good life for their employees, this has a better radiance, of course (CHf). While it can be supported through investments in terms of employees' health and wellbeing, e.g., fruit baskets at the office and healthy meals at the canteen (CHm), working together was also seen as essential by a Slovenian employee representative: In our company, we strive for a family-friendly economy, a comfortable working atmosphere, sophisticated relationships between colleagues, respect for human beings, etc. The most important aspects of a good life at work are 
positive and supportive relations within the company, but also corporate social responsibility for our environment (Sm).

One employee representative even stressed the relevance of a good life for social wellbeing, expressing her concern as follows: A system that is not caring for the good life of its people is going to break down sooner or later (Sf). A German colleague shared her sentiment: At the moment, I believe that the good life at work is endangered, since there are new developments that impede the realization of a good life for employees; for example, trying to recruit external workers and not having to pay them according to the collective agreement (Gf).

The elaborations above indicate that a good life is not only constituted at work and influenced by organizational commitments (e.g., investments in employee health, employee well-being, or SRHRM), but is also heavily influenced by people's lives outside of their workplace. So, while individuals must fulfill their part in guaranteeing a good working life, corporations themselves are seen as enablers of a good life by fulfilling multiple tasks and acts of appreciation in the form of employee benefits, such as gym memberships, fruit baskets, educational classes, cooking classes (Am), fairness, adequate wages, and optimal work conditions (Am). In selected cases, even the wellbeing of others was put ahead of people's own, such as in the case of donating, helping (Am), or giving a hand to people or organizations that are not doing well (Gf). Through these elaborations, the versatile nature of CSR and SRHRM becomes obvious.

\subsection{Potential for Realizing a Good Life at Work}

Even though employee representatives perceive themselves to be in a position to influence how a good life is implemented in the workplace, they are not necessarily in charge of this task alone. Instead, they consider it a shared task. The good life can be implemented in the workplace if all parties work together and cooperate (Af). One Slovenian employee representative remarked: Usually, the PR department is responsible for good communication, but we had some bad experiences. They are only concerned with the outer appearance of the company. Employee representatives, together with the management, have now taken over this role, and it is working quite well (Sm). A shared responsibility for a good life was also noted by respondents in other countries: Everyone is responsible to point out injustices (Gm); well, I think it's not just one person in charge of its implementation, the corporate agencies and also the individual people and every actor in the system is in charge of it (GBm); theoretically, everyone in the company to varying degrees. Realistically, it's managers and HR (USm). A similar answer was provided by a Finish employee representative: Sometimes I am and the HR manager. Or we both go to the offices and ask what's the problem (Fm). Once again, the notion of individuals being the organizations' core assets receives recognition, underlining the relevance of SRHRM.

The interview results highlight that companies are (morally) able to act-as already attested by Kessler [88], Nöcker [89], and Euwema et al. [90]—and that employee representatives can exploit their communicative freedom of action, at least to a certain extent. In this context, they occupy a multitude of roles and are classified as "linking pins", as described by Likert and Likert [32]. Most roles are either dictated by the respective legal framework of the individual countries (CSR indices, certificates) or political contexts (sustainability agenda). Communication is seen as the "molar concept", as every communicative act influences moral agency. The role of communication and the character of communication flows, nonetheless, depend on the degree of institutionalization. Surprisingly, the necessity of putting agreements into writing was only brought up by two Austrian employee representatives, who postulated that the rules of play must be put in writing (Am) because, when writing down bargaining agreements, these written documents can be used to keep everyone informed. As such, they become a collective agreement between employees and employee representatives (Af). 


\section{Discussion of Results}

The present contribution intended to embed philosophical discussions about individual and collective responsibility in the entrepreneurial context and, above all, to discuss the possibilities and limitations of the communicative realization of responsibility within the organizational context. This responsibility was ascribed to employee representatives, who-despite extending the responsibilities of HRM-have received limited academic attention to date. The present contribution highlighted that the role of the works council is generally strongly tied to norms, values, and ethical principles. Although there was agreement that a good working life reflects on everything people do-therefore, in the performance at work as well $(\mathrm{CHm})$, the concept was conceptualized very distinctively in different parts of the world. It became clear that in countries where fixed structures and works council models are either dictated by law or have been negotiated, employee representatives have little scope for communicative negotiation processes concerning new values, shared meaning, and organizational culture in relation to sustainability as a normative framework for realizing a good life at work. In countries in which no regulations can be found, their tasks are less comprehensive and limited in scope.

The concept of moral agency, which is claimed by different roles or even realized within different complementary roles, was complemented by a specific understanding of communication as constitutive for employee representatives' agency itself. By putting employee representatives at the focus of research, the interview data showed that moral agency in the context of a good working life requires a specific definition of responsibility. In every role that was brought up in the interviews, both the process of taking responsibility and the allocation of responsibility were reflected-from gatekeeper over spokesperson to medium. The interviewed employee representatives further described five aspects as central to securing a good working life:

- Control (i.e., implementing and realizing the legal framework, particularly in Germany and Austria).

- Cognitive and affective dimensions of responsibility, such as solidarity, helping others, pursuing happiness, and having a sympathetic ear.

- "Fulfilling expectations" of both the management and employees and, thus, occupying the role of a linking pin.

- Following managerial "directives" that limit their potential for involvement.

- Exercising moral agency, which is closely linked to sustainability, sustainable operations, and SRHRM, and - as it is realized through communication-"conversational responsibility".

These criteria also correspond to the works councils' tasks that were identified in the literature and that involve aspects of the psychology of working theory and decent work. At the same time, they account for the management's role in securing a good life, as it-to varying degrees-delegates responsibility to employee representatives as linking pins. Considering employee representatives' different cultural backgrounds, it becomes clear that the individual works council models considerably influence employee representatives' perceptions and the corresponding responsibility, but less so the communicative understanding of roles or the role of communication in general. Table 1 provides an overview of two opposing models and their respective focuses on communication flows and processes (German model with a high degree of institutional responsibility as compared to the Anglo-Saxon model with a more pronounced individual-ethical perspective).

A comparison of the interviews against the background of the societal and cultural contexts was very fruitful in the sense of comparing employee representatives with a high degree of institutionalized responsibility (German model) to those with a low degree of legal regulation and institutionalized moral agency (Anglo-Saxon model). This might correspond with more recent developments in Europe that have led to the establishment of more participatory management styles when compared to the US and Great Britain, where management is still rather authoritative and sometimes even exploitive [31]. 
Table 1. Institutionalized and individual responsibilities involved in guaranteeing a good working life (the authors). For the sake of simplicity, only two models will be compared.

\begin{tabular}{|c|c|c|}
\hline & $\begin{array}{l}\text { Institutionalized Responsibility } \\
\text { (German Model) }\end{array}$ & $\begin{array}{l}\text { Individual Responsibility } \\
\text { (Anglo-Saxon Model) }\end{array}$ \\
\hline The good life & negotiated, fixed & to be negotiated \\
\hline $\begin{array}{l}\text { Employee representatives } \\
\text { and their responsibilities }\end{array}$ & $\begin{array}{c}\text { reactive: securing a good } \\
\text { working life ("control organ", "gatekeeper") }\end{array}$ & $\begin{array}{l}\text { (pro)-active: defines a good working life or is } \\
\text { up for negotiation ("medium", "facilitator") }\end{array}$ \\
\hline Problems, challenges & $\begin{array}{l}\text { value incongruence, individual character of the } \\
\text { "good" often contradicts institutionalized } \\
\text { forms (pluralistic society) }\end{array}$ & $\begin{array}{l}\text { value congruence } \\
\text { (discourse) }\end{array}$ \\
\hline $\begin{array}{l}\text { Influence of individual values } \\
\text { on organizational structure }\end{array}$ & $x^{2}$ & high \\
\hline Communication flows & top-down, formal, indirect & bottom-up, dialogic, direct, personal \\
\hline
\end{tabular}

Distinctions occur on five different levels:

(1) The good life: In countries in which legal regulations ensure that organizations implement measures for employee wellbeing, notions of a good life are rather seen as a given, defined by statutes and positioning papers, and serve as a basis for the work of both works councils and employee representatives. The opposite is true in countries where no such regulations exist; there, notions of what constitutes a good life must be negotiated.

(2) Employee representatives and their responsibilities: Given their organizational embeddedness and legal foundation, employee representatives' roles are mostly reactive. In the German model, for instance, employee representatives must ensure that employees' interests are secured and that corporate decisions do not put employees at a disadvantage. This, however, is not the case in countries with weak or no representation culture, as employee representatives take a pro-active role in defining a good life and support its implementation on the organizational level.

(3) Problems and challenges: The largest challenges arise in the context of defining what a good life entails. The interview findings support the assumption that definitions of a good life are quite distinct and usually reflective of individuals' preferences and needs. In countries with institutionalized responsibility, little room for the consideration of personal preferences is provided, which can result in a value incongruence. In countries in which a good life presents an individual responsibility, a value congruence can be more readily achieved, since a good life is defined jointly in the process of discursive exchanges.

(4) Influence of individual values on organizational structure: Countries with strong employee representation only marginally consider employees' personal values in defining a good life. Instead, they pursue a broad, institutionalized approach. In the AngloSaxon model, on the other hand, a good life is expressive of individual values and preferences, as it is communicatively negotiated and reflective of individuals' desires and needs.

(5) Communication flows: Communication in the German model is-due to the close cooperation of employee representatives with management and/or HRM, as well as the institutionalized approach to the good life (which is anchored in legal regulations) rather top-down and formal. This, however, is not the case in countries that take an individualized approach to responsibility; since the good life is negotiated discursively, communication starts from the bottom up, is dialogic and rather personal.

With a focus on realizing a good working life, we can conclude that communication "dictates" or constitutes roles of responsibility.

The study presented herein was able to point out that even though employee representatives are crucial in ensuring a good working life and can be seen as an extension to SRHR (particularly in the case of participative management systems), their efforts alone will not do. To succeed, a more differentiated organizational approach to ethical engagements 
and institutionalized negotiation processes related to the principles of a good working life is required. This suggests that institutional and individual perspectives must not be considered as substitutes, but that they are reciprocally linked to one another. This link was also established in the interviews, where a shared responsibility for a good working life was expressed. This further insinuates that organizations presuppose an individual's readiness to be committed and adapt one's own actions to corresponding ethical principles. At the same time, organizations should offer a support system (in the form of employee representatives or linking pins) that is increasingly conditioned by a newly found awareness for employees as an organization's core assets.

\section{Conclusions}

A recognition of works councils' roles in the process of implementing and securing a good working life seems inevitable against the background of the Sustainable Development Goals, which specifically address a "good working life" as part of Goal 8 [1]. HRM has evolved in the past decades, increasingly taking the form of SRHRM, in which an organization's CSR activities take its employees' welfare and wellbeing into account $[5,18]$. Past studies have also addressed the benefits of healthy workers for companies [20,137-139].

Broadening the scope of works council research-and integrating it into theories of organizational, CSR, and sustainability communication-the present theoretical considerations and exemplary empirical results show that even if works councils are solely given an information role in a company, they also bear responsibility for a good working life (in the form of entrepreneurial co-management; [119]). This attribution, however, needs to be complemented by an individual dimension of responsibility, which can foster the realization of a good working life, suggesting that in addition to organizations or employers, employees themselves are responsible for communicatively realizing a good working life. Besides HRM, they can turn to employee representatives, who serve as their extended voices (or linking pins) and can assist them in meeting their needs. A good working life, thereby, falls into the scope of participative management and SRHRM, in which employee welfare and wellbeing are prioritized [41]. To exploit the potential for increasing employees' experiences of the workplace and, consequently, their wellbeing, institutional/organizational and individual responsibility must exist side by side and presuppose both organizational commitment and an individual willingness to participate in the implementation of a good life in the workplace. In this context, employee representatives might present a viable solution in facilitating both decent work and a good working life.

\section{Limitations and Directions for Future Research}

There are several limitations to the research project at hand. First, though the data were collected 6 years ago, we do not believe that the results are outdated. Given that COVID-19 has elevated employers' concern for employees' wellbeing and has forced organizations to put more thought into employers' roles guaranteeing a high quality of employees' lives at work, the topic is up to date and might even increase the relevance of a joint approach towards a good working life that is based on both institutionalized and individual responsibility.

Second, the sample was rather limited and not equally distributed among the individual countries. Third, even though interviews were conducted in several countries, the countries included in this study were chosen at random. Therefore, it would be advisable to replicate the study in countries that might employ mixed systems. An additional aspect that would be interesting to study is the identification of the roles that employee representatives hold within companies and further inquire employers' perspectives of employee representatives' roles. Additionally, a comparison of organizations from different cultural backgrounds (e.g., with and without strong social partnerships) might prove fruitful. 
Author Contributions: Conceptualization, I.K. and F.W.; methodology, I.K. and F.W.; software, I.K.; validation, I.K.; formal analysis, I.K.; investigation, F.W.; data curation, I.K.; writing-original draft preparation, I.K.; writing-review and editing, I.K. and F.W.; visualization, F.W.; project administration, I.K. All authors have read and agreed to the published version of the manuscript.

Funding: This research received no external funding.

Institutional Review Board Statement: Ethical review and approval were waived for this study, due to the fact that Austrian law and university research policy do not demand approval from an external ethics committee in case of interviews. Nonetheless, all interview participants gave their oral informed consent to the recording and for the records to be used for research purposes.

Informed Consent Statement: Given the topics' sensitive nature, participants were informed that participating in the study was voluntary. They were further assured that there were no correct or incorrect answers, and they were asked to answer questions as honestly as possible. In addition, respondents were assured of the anonymity and confidentiality of their responses.

Data Availability Statement: Interview data is available upon request.

Conflicts of Interest: The authors declare no conflict of interest.

\section{Appendix A}

Interview Guideline

Enterprises fulfill some core tasks, including the covering of basic human needs in order to ensure societal wellbeing. Thus, their duties evolve around guaranteeing a "good life" for both society in general and for humans-their workforce-in particular.

The scientific literature offers a broad range of definitions and structural guidelines that are meant to support businesses in their endeavors (see the literature on CSR, CR vs. codices, guidelines, and special-interest organizations). It specifically addresses the good life and lists further suggestions for how it can be improved. As they aim at achieving long-lasting success, companies turn to these guidelines. However, how are they utilized within the company? For that reason, the study of a good life within an enterprise needs to thematize the following questions:

1. What do enterprises do?

2. How do they do it (which measures or instruments are applied)?

3. Who is responsible?

1. Who is in charge of noticing external impulses?

2. Within the firm, who is in charge of the implementation of entrepreneurial engagements?

3. Who is responsible for warranting the permanence of these engagements (contingency)?

In all these processes, the importance of communication must not be underestimated and requires "a look behind the scenes" in order to deconstruct organizational communication at its core. For this exact reason, employee representatives are suitable subjects of investigation for the present project. They function as critical entities and observers, and their main tasks evolve around uncovering misconceptions and contradictions, as well as deficits.

\section{References}

1. UN. Goal 3: Ensure Healthy Lives and Promote Well-Being for All at All Ages. 2017. Available online: https://www.un.org/sus tainabledevelopment/health/ (accessed on 15 May 2021).

2. Iqbal, K.; Ahmad, M.H. Effect of psychological capital on organizational commitment: Mediating role of psychological empowerment. Abasyn J. Soc. Sci. 2017, 9, 72-87.

3. Lee, M.D.P. A review of the theories of corporate social responsibility: Its evolutionary path and the road ahead. Int. J. Manag. Rev. 2008, 10, 53-73. [CrossRef]

4. Porter, M.E.; Kramer, M.R. Strategy and society: The link between competitive advantage and corporate social responsibility. Harv. Bus. Rev. 2006, 84, 78-92. 
5. Iqbal, K.; Zahid, M.S.; Arif, M. How Does Socially Responsible Human Resource Management Influence Employee Well-Being? In Responsible Business in Uncertain Times and for a Sustainable Future. CSR, Sustainability, Ethics E Governance; Capaldi, N., Idowu, S., Schmidpeter, R., Brueckner, M., Eds.; Springer: Cham, Switzerland, 2019; pp. 207-218. [CrossRef]

6. Wright, M.; Gardner, M.; Moynihan, M.; Allen, R. The relationship between HR practices and firm performance: Examining casual order. Pers. Psychol. 2005, 58, 409-446. [CrossRef]

7. Stavrou, E.; Brewster, C.; Charalambous, C. Human resource management and firm performance in Europe through the lens of business systems: Best fit, best practice or both? Int. J. Hum. Resour. Manag. 2010, 21, 933-962. [CrossRef]

8. Sirca, N.; Babnik, K.; Breznik, K. Towards organizational performance. Understanding human resource management climate. Ind. Manag. Data Syst. 2013, 113, 367-384. [CrossRef]

9. Bednall, T.; Sanders, K.; Runhaar, P. Stimulating informal learning activities through perceptions of performance appraisal quality and management system strength: A two-wave study. Acad. Manag. Learn. Educ. 2014, 13, 45-61. [CrossRef]

10. Ribeiro, J.L.; Gomes, D. Other Organizational Perspectives on the Contribution of Human Resources Management to Organizational Performance. In Organizational Management; Machado, C., Davim, J.P., Eds.; Palgrave Macmillan: London, UK, 2016; pp. 63-106. [CrossRef]

11. Barrick, M.; Thurgood, G.; Smith, T.; Courtright, S. Collective organizational engagement: Linking motivational antecedents, strategic implementation, and firm performance. Acad. Manag. J. 2015, 58, 111-135. [CrossRef]

12. Weder, F.; Karmasin, M.; Krainer, L.; Voci, D. Introduction. In The Sustainability Communication Reader; Weder, F., Krainer, L., Karmasin, M., Eds.; Springer: Wiesbaden, Germany, 2021; pp. 1-12.

13. Bourne, M.; Pavlov, A.; Franco-Santos, M.; Lucianetti, L.; Mura, M. Generating organisational performance: The contributing effects of performance measurement and human resource management practices. Int. J. Oper. Prod. Manag. 2013, 33, 1599-1622. [CrossRef]

14. Kuisma, J. Managing Corporate Responsibility in the Real World-Lessons from the Frontline of CSR; Springer: Wiesbaden, Germany, 2017. [CrossRef]

15. Tyson, S.; Fell, A. Evaluating the Personnel Function; Hutchinson: London, UK, 1986.

16. Shen, J. Developing the concept of socially responsible international human resource management. Int. J. Hum. Resour. Manag. 2011, 22, 1351-1363. [CrossRef]

17. Karmasin, M.; Weder, F. Organisationskommunikation und CSR; Neue Herausforderungen an Kommunikationsmanagement und PR: Münster, Germany, 2008.

18. Shen, J.; Benson, J. When CSR is a social norm: How socially responsible human resource management affects employee work behavior. J. Manag. 2016, 42, 1723-1746. [CrossRef]

19. Waring, P.; Lewer, J. The impact of socially responsible investment on human resource management: A conceptual framework. J. Bus. Ethics 2004, 52, 99-108. [CrossRef]

20. Harter, J.K.; Schmidt, F.L.; Hayes, T.L. Business-unit-level relationship between employee satisfaction, employee engagement, and business outcomes: A meta-analysis. J. Appl. Psychol. 2002, 87, 268-279. [CrossRef]

21. Fenwick, T.; Bierema, L. Corporate social responsibility: Issues for human resource development professionals. Int. J. Train. Dev. 2008, 12, 24-35. [CrossRef]

22. Eurofund. Board-Level Employee Representation in Europe. 1998. Available online: http://www.eurofound.europa.eu/observat ories/eurwork/comparative-information/board-level-employee-representation-in-europe (accessed on 15 May 2021).

23. Guignon, C.B. The Good Life; Hackett: Indianapolis, IN, USA, 1999.

24. Wirtz, D.; Chiu, C.Y.; Diener, E.; Oishi, S. What constitutes a good life? Cultural differences in the role of positive and negative affect in subjective well-being. J. Personal. 2009, 77, 1167-1196. [CrossRef]

25. Lee, T. The Good Life; Moody Press: Chicago, IL, USA, 2012.

26. Sirgy, M.J.; Efraty, D.; Siegel, P.; Lee, D.-J. A new measure of quality of work life (QWL) based on need satisfaction and spillover theory. Soc. Indic. Res. 2001, 55, 241-302. [CrossRef]

27. Nasl Saraji, G.; Dargahi, H. Study of Quality of Work Life (QWL). Iran. J. Public Health 2006, 35, 8-14.

28. Blustein, D.L. The role of work in psychological health and well-being: A conceptual, historical, and public policy perceptive. Am. Psychol. 2008, 63, 228-240. [CrossRef] [PubMed]

29. Blustein, D.L. A relational theory of working. J. Vocat. Behav. 2011, 79, 1-17. [CrossRef]

30. ILO. Decent Work Indicators. 2013. Available online: https://www.ilo.org/wcmsp5/groups/public/---dgreports/---integration /documents/publication/wcms_229374.pdf (accessed on 15 May 2021).

31. Morris, T.; Pavett, C.M. Management Style and Productivity in Two Cultures. J. Int. Bus. Stud. 1991, 23, 169-179. [CrossRef]

32. Likert, R.; Likert, J.G. New Ways of Managing Conflict; McGraw-Hill: New York, NY, USA, 1976.

33. Wilson, J.H. Authority in the 21st century: Likert's System 5 Theory. Emerg. Leadersh. Journeys 2010, 3, 33-41.

34. Likert, R. System 4: A resource for improving public administration. Public Adm. Rev. 1981, 41, 674-678. [CrossRef]

35. Eagly, A.H.; Johannesen-Schmidt, M.C.; van Engen, M.L. Transformational, transactional, and laissez-faire leadership styles: A meta-analysis comparing women and men. Psychol. Bull. 2003, 129, 569-591. [CrossRef]

36. American Psychological Association. The State Of Our Nation. Available online: https://www.apa.org/news/press/releases/st ress/2017/state-nation.pdf (accessed on 15 February 2021). 
37. Yang, L.Q.; Caughlin, D.E.; Gazica, M.W.; Truxillo, D.M.; Spector, P.E. Workplace mistreatment climate and potential employee and organizational outcomes: A meta-analytic review from the target's perspective. J. Occup. Health Psychol. 2014, $19,315-335$. [CrossRef]

38. HBR. How to Stop Thinking About Work at 3am. 2020. Available online: https://hbrascend.org/topics/how-to-stop-thi nking-about-work-at-3am/?fbclid=IwAR2UY_Efw66aSGhxp7av847cW1lbnupfQ_IBdjojg9ncjlHroUXNya3kpIw (accessed on 15 May 2021).

39. Wrike. Crash and Burnout: Is Workplace Stress the New Normal? 2019. Available online: https://www.wrike.com/blog/stressepidemic-report-announcement/ (accessed on 15 February 2021).

40. Ferry, K. Workplace Stress Continues to Mount. 2018. Available online: https://www.kornferry.com/insights/articles/workplac e-stress-motivation (accessed on 15 May 2021).

41. Faver, L.; Fuerst, M.E. Does good corporate governance include employee representation? Evidence from German corporate boards. J. Financ. Econ. 2006, 82, 673-710. [CrossRef]

42. Haidpeter, T.; Hertwig, M.; Rosenbohm, S. (Eds.) Employee Representation in Multinational Companies; Palgrave Macmillan: Cham, Switzerland, 2019.

43. Charlwood, A.; Terry, M. 21st-century models of employee representation: Structures, processes and outcomes. Ind. Relat. J. 2007, 38, 320-337. [CrossRef]

44. Bandura, A. Self-efficacy. In The Corsini Encyclopedia of Psychology; Weiner, I.B., Corsini, R.J., Eds.; Wiley: Hoboken, NJ, USA, 2010. [CrossRef]

45. Weder, F.; Einwiller, S.; Eberwein, T. Heading for New Shores. Impact orientation of CSR communication and the need for communicative responsibility. Corp. Commun. Int. J. 2019, 24, 198-211. [CrossRef]

46. Wagner, R. Interne Kommunikation. In CSR und Compliance. Management-Reihe Corporate Social Responsibility; Kleinfeld, A., Martens, A., Eds.; Springer Gabler: Berlin/Heidelberg, Germany, 2018; pp. 239-260.

47. Rasche, A.; Morsing, M.; Moon, J. Corporate Social Responsibility. Strategy, Communication, Governance; Cambridge University Press: Cambridge, UK, 2017.

48. Gond, J.; Crane, A. Corporate social performance disoriented: Saving the lost paradigm? Bus. Soc. 2010, 49, 677-703. [CrossRef]

49. Weder, F.; Krainer, L.; Karmasin, M. The Sustainability Communication Reader. A Reflective Compendium; Springer: Wiesbaden, Germany, 2021.

50. Weder, F.; Lemke, S.; Tungarat, A. (Re)storying Sustainability: The Use of Story Cubes in Narrative Inquiries to Understand Individual Perceptions of Sustainability. Sustainability 2019, 11, 5264. [CrossRef]

51. Godemann, J.; Michelsen, G. Sustainability Communication. Interdisciplinary Perspectives and Theoretical Foundations; Springer: Heidelberg, Germany; London, UK; New York, NY, USA, 2011.

52. Frank, A.K. What is the story with sustainability? A narrative analysis of diverse and contested understandings. J. Environ. Stud. Sci. 2017, 7, 310-323. [CrossRef]

53. Newig, J.; Schulz, D.; Fischer, D.; Hetze, K.; Laws, N.; Lüdecke, G.; Rieckmann, M. Communication Regarding Sustainability: Conceptual Perspectives and Exploration of Societal Subsystems. Sustainability 2013, 5, 2976-2990. [CrossRef]

54. Röttger, U.; Kobusch, J.; Preuse, J. Grundlagen der Public Relations. Eine Kommunikationswissenschaftliche Einführung, 3rd ed.; Spinger VS: Wiesbaden, Germany, 2018.

55. Hoffjann, O.; Huck-Sandhu, S. (Eds.) UnVergessene Diskurse. 20 Jahre PR- und Organisationskommunikationsfroschung; Spinger VS: Wiesbaden, Germany, 2013.

56. Weder, F. Organisationskommunikation und PR; Facultas UTB: Wien, Austria, 2009.

57. Werder, K.P.; Nothhaft, H.; Verčič, D.; Zerfass, A. Strategic Communication as an Emerging Interdisciplinary Paradigm. Int. J. Strateg. Commun. 2018, 12, 333-351. [CrossRef]

58. Schoeneborn, D.; Kuhn, T.R.; Kärreman, D. The communicative constitution of organization, organizing, and organizationality. Organ. Stud. 2019, 40, 475-496. [CrossRef]

59. Merten, K. Der konstruktivistische Ansatz. In Handbuch der Public Relations; Fröhlich, R., Szyszka, P., Bentele, G., Eds.; Spinger VS: Wiesbaden, Germany, 2015; pp. 175-189.

60. Hoffjann, O. Vertrauen in Public Relations; Spinger VS: Wiesbaden, Germany, 2013.

61. Schneider, A.; Schmidpeter, R. Corporate Social Responsibility: Verantwortungsvolle Unternehmensführung in Theorie und Praxis; Springer: Berlin, Germany, 2012.

62. Gazdar, K.; Habisch, A.; Kirchhoff, K.R.; Vaseghi, M. Erfolgsfaktor Verantwortung: Corporate Social Responsibility professionell managen; Springer: Berlin, Germany, 2006.

63. Der Betriebsrat. Betriebsräte in Westeuropa. Der Betr. 2005, 4, 19-25.

64. Fulton, L. Worker representation in Europe. 2013. Available online: http://www.worker-participation.eu/National-IndustrialRelations / Across-Europe/Workplace-Representation2 (accessed on 15 May 2021).

65. Financial Times. Definition of Employee Representation. 2015. Available online: http://lexicon.ft.com/Term?term=employee-re presentation (accessed on 15 May 2021).

66. Bryson, A.; Charlwood, A.; Forth, J. Worker voice, managerial response and labour productivity: An empirical investigation. J. Intern. Relat. Dev. 2006, 37, 438-455. [CrossRef] 
67. Vinković, M. Works councils in Croatia: A form of the protection of workers' rights and/or the employer's interest? In Workers' Representation in Central and Eastern Europe. Challenges and Opportunities for the Works Councils' System; Blanpain, R., Lyutov, N., Eds.; Kluwer Law International: Alphen aan den Rijn, The Netherlands, 2014; pp. 37-51.

68. Christensen, S.; Westenholz, A. Employee Representatives as Company Strategic Actors in an Enacted World. Arctic Res. J. 2001, 1, 78-90.

69. Rose, C. The Challenges of Employee-Appointed Board Members for Corporate Governance: The Danish Evidence. Eur. Bus. Org. Law Rev. 2008, 9, 215-235. [CrossRef]

70. Ginglinger, E.; Megginson, W.; Waxin, T. Employee ownership, board representation, and corporate financial policies. J. Corp. Financ. 2011, 17, 868-887. [CrossRef]

71. Ferracci, P. IFRS and the Works Council in France. In IFRS in a Global World; Bensadon, D., Praquin, N., Eds.; Springer: Cham, Switzerland, 2013; pp. 101-114.

72. Frick, B.; Bermig, A. Mitbestimmung und Unternehmensperformance: Der Einfluss von Arbeitnehmervertreter im Aufsichtsrat auf Unternehmenswert. Die Betr. 2011, 71, 281-304.

73. Duran, M.; Pull, K. Der Beitrag der Arbeitnehmervertreter zur fachlichen und geschlechtlichen Diversität von Aufsichtsräten: Erkenntnisse aus einer qualitativ-explorativen Analyse. Ind. Bezieh. 2014, 21, 329-351. [CrossRef]

74. Hagen, I.M. Employee elected directors on company boards: Stakeholder representatives or the voice of labour? In Rethinking Corporate Governance: From Shareholder Value to Stakeholder Value; Blanpain, R., Bromwich, W., Rymkevich, O., Senatori, I., Eds.; Kluwer Law International: Alphen aan den Rijn, The Netherlands, 2011; pp. 121-140.

75. Williamson, J.; Driver, C.; Kenway, P. Beyond Shareholder Value. The Reasons and Choices for Corporate Reform; TUC: London, UK, 2014; Available online: https:/ / www.tuc.org.uk/sites/default/files/BSV.pdf (accessed on 15 May 2021).

76. Calvo, J.; Vigneau, C.; Belopavlovic, N.; Rodriguez Contreras, R.; Fulton, L. Employee Representatives in an Enlarged Europe; Office for Official Publications of the European Communities: Luxembourg, 2008; Volume 1.

77. Haidar, J.I. Investor protections and economic growth. Econ. Lett. 2009, 103, 1-4. [CrossRef]

78. Conchon, A. Workers' Voice in Corporate Governance. A European Perspective; TUC: London, UK, 2013. Available online: https: //www.tuc.org.uk/sites/default/files/workers-voice-in-corporate-governance_0.pdf (accessed on 15 May 2021).

79. Devinatz, V.G. "Glorified Messengers from Management" or "Legitimate Unionism"? An Analysis of Local Independent Unions in the Post-Company Union Era. Empl. Responsib. Rights J. 2006, 18, 231-247. [CrossRef]

80. Kaufmann, B.E. The case for the company union. Labor Hist. 2000, 41, 321-350. [CrossRef]

81. Kaufmann, B.E.; Taras, D.G. Nonunion Employee Representation: History, Contemporary Practice, and Policy; M.E. Sharpe: Armonk, NY, USA, 2000.

82. Kluge, N. Corporate governance with co-determination: A key element of the European social model. Transfer 2005, 11, 163-177. [CrossRef]

83. Fulton, L. (Ed.) The Forgotten Resource: Corporate Governance and Employee Board-Level Representation. The Situation in France, the Netherlands, Sweden and the UK; Hans-Böckler-Stiftung: Düsseldorf, Germany, 2006. Available online: https:/ /www.boeckler.de/ pdf/p_edition_hbs_190.pdf (accessed on 7 August 2019).

84. Gospel, H.; Pendleton, A. Corporate Governance and Employee Participation. In The Oxford Handbook of Participation in Organizations; Wilkinson, A., Gollan, P.J., Marchington, M., Lewin, D., Eds.; Oxford University Press: Oxford, UK, 2010; pp. 504-525.

85. Gelter, M. The Dark Side of Shareholder Influence: Managerial Autonomy and Stakeholder Orientation in Comparative Corporate Governance. Harv. Int. Law J. 2009, 50, 129-194.

86. Hocke, S. Konflikte im Betriebsrat als Lernanlass; Springer: Wiesbaden, Germany, 2012.

87. Wibberly, G.; Saundry, R. From Representation Gap to Resolution Gap: Exploring the Role of Employee Voice in Conflict Management. In Reframing Resolution: Innovation and Change in the Management of Workplace Conflict; Saundry, R., Latreille, P., Ashman, I., Eds.; Springer: Wiesbaden, Germany, 2016; pp. 127-148.

88. Kessler, F. The Governance of Supplementary Pension Schemes and the Role of Employee Representatives: A Story of Paradoxes. In Steuerung der Betrieblichen Altersversorgung in Europa: Garantierte Sicherheit? Kaufmann, O., Hennion, S., Eds.; Springer: Berlin, Germany, 2011; pp. 293-303.

89. Nöcker, R. Pensions governance: The control of occupational pension schemes in the UK and Germany. Pensions Int. J. 2001, 6, 227-248. [CrossRef]

90. Euwema, M.; Munduate, L.; Elgoibar, P.; Pender, E.; Belen Garcia, A. (Eds.) Promoting Social Dialogue in European Organizations; Springer: Berlin, Germany, 2015. [CrossRef]

91. O'Connell, P.J.; Russell, H.; Williams, J.; Blackwell, S. The Changing Workplace: A Survey of Employees' Views and Experiences; National Centre for Partnership \& Performance (NCPP): Dublin, Ireland, 2003.

92. van den Berg, A.; Grift, Y.; van Witteloostuijn, A. Works Councils and Organizational Performance. J. Labor Res. 2011, 32, 136-156. [CrossRef]

93. Koukiadaki, A. The evolution of employee involvement in European labour law. ERA Forum 2011, 11, 601-619. [CrossRef]

94. Nerdinger, F.W.; Wilke, P.; Röhrig, R.; Stracke, S. Innovation und Beteiligung in der betrieblichen Praxis: Strategien, Modelle und Erfahrungen in der Umsetzung von Innovationsperspektiven; Springer: Wiesbaden, Germany, 2010. 
95. Schlüter, S. Participation of works councils: Opportunities and Risks Involved in Participation of Works Councils in the Critical Review Process Against the Background of the Current Political Debate. Int. J. Life Cycle Assess. 2000, 5, 2-3. [CrossRef]

96. Rabe, M.; Giacomuzzi, S.; Nübling, M. Psychosocial Workload and Stress in the workers representative. BMC Public Health 2012, 12, 909. [CrossRef]

97. Sprenger, W. Innovation, Trade Unions and Works Councils in a European Perspective: Experiences from Selected EU Member States. In Innovation und Beteiligung in der betrieblichen Praxis: Strategien, Modelle und Erfahrungen in der Umsetzung von Innovationsperspektiven; Nerdinger, F.W., Wilke, P., Röhrig, R., Stracke, S., Eds.; Springer: Wiesbaden, Germany, 2010; pp. 207-226.

98. Malik, A. HRM and ER: A Strategic Perspective. In Strategic Human Resource Management and Employment Relations; Springer Texts in Business and Economics; Malik, A., Ed.; Springer: Singapore, 2018. [CrossRef]

99. Malik, A. Strategic Choice and SHRM \& ER. In Strategic Human Resource Management and Employment Relations; Springer Texts in Business and Economics; Malik, A., Ed.; Springer: Singapore, 2018. [CrossRef]

100. Ulrich, D.; Brockbank, W. The HR Value Proposition; Harvard Business School Press: Boston, MA, USA, 2005.

101. Looise, J.C.; Drucker, M. Dutch work councils in times of transition: The effects of changes in society, organizations and work on the position of work councils. Econ. Ind. Democr. 2003, 24, 379-409. [CrossRef]

102. Nerdinger, F.W.; Wilke, P. (Eds.) Erfolgsfaktor Beteiligungskultur. Ergebnisse aus dem Projekt TiM-Transfer Innovativer Unternehmensmilieus; Hampp: München/Mering, Germany, 2008.

103. Nerdinger, F.W.; Wilke, P. (Eds.) Beteiligungsorientierte Unternehmenskultur. Erfolgsfaktoren, Praxisbeispiele und Handlungskonzepte; Gabler: Wiesbaden, Germany, 2009.

104. Stracke, S. Betriebsräte und Innovation. Empirische Befunde, Beschäftigungsorientierung und mögliche Aufgabenfelder; Arbeitspapier Nr. 3 aus dem Projekt TiM; Universität Rostock: Rostock, Germany, 2006.

105. Barnard, C. EC Employment Law, 2nd ed.; Oxford University Press: Oxford, UK, 2006.

106. Fulton, L. Board-Level Representation in Europe. 2015. Available online: http://www.worker-participation.eu/National-Industr ial-Relations / Across-Europe/Board-level-Representation2 (accessed on 15 May 2021).

107. Mattke, S.; Kapinos, K.; Caloyeras, J.P.; Taylor, E.A.; Batorsky, B.; Liu, H.; Van Busum, K.R.; Newberry, S. Workplace wellness programs: Services offered, participation, and incentives. Rand Health Q. 2015, 5, 7.

108. Boxall, P.; Purcell, J. Strategy and Human Resource Management; Palgrave Macmillan: Basingstoke, UK, 2003.

109. Freeman, R.B.; Medoff, J.L. What Do Unions Do? Basic Books: New York, NY, USA, 1984.

110. Hammer, T.H. Nonunion representation form: An Organizational behavior perspective. In Nonunion Employee Representation; Kaufmann, B.E., Taras, D.G., Eds.; Routledge: London, UK, 2000; pp. 176-196.

111. Dyne, L.V.; Ang, S.; Botero, I.C. Conceptualizing Employee Silence and Employee Voice as Multidimensional Constructs. J. Manag. Stud. 2003, 40, 1359-1392. [CrossRef]

112. Hogarth, K.; Hutchinson, M.; Scaife, W. Corporate Philanthropy, Reputation Risk Management and Shareholder Value: A Study of Australian Corporate giving. J. Bus. Ethics 2018, 151, 375-390. [CrossRef]

113. Dembek, K.; Singh, P.; Bhakoo, V. Literature Review of Shared Value: A Theoretical Concept or a Management Buzzword? J. Bus. Ethics 2016, 137, 231-267. [CrossRef]

114. Smythe, C.F. Public-Private Sector Multi-Employer Collective Bargaining: The Role of the Employer Representative. Labor Law J. 1971, 4, 498-508.

115. Bernhardt, A.; Spiller, M.W.; Theodore, N. Employers Gone Rogue: Explaining Industry Variation in Violations of Workplace Laws. Ind. Labor Relat. Rev. 2013, 66, 808-832. [CrossRef]

116. Roberts, J.; van den Steen, E. Human capital and corporate governance. In Corporate Governance: Essays in Honor of Horst Albach; Albach, H., Schalbach, J., Eds.; Springer: Berlin, Germany, 2001; pp. 128-144.

117. Bryson, A.; Barth, E.; Dale-Olsen, H. The Effects of Organizational Change on Worker Well-Being and the Moderating Role of Trade Unions. ILR Rev. 2013, 66, 989-1011. [CrossRef]

118. Harrison, D.; Roy, M.; Haines, V. Union Representatives in Labour-Management Partnerships: Roles and Identities in Flux. Br. J. Ind. Relat. 2009, 49, 411-435. [CrossRef]

119. Nettelstroh, W.; Schilling, G.; Vanselow, A. Innovationspartnerschaft im Betrieb-Gewerkschaftliches Unterstützungsangebot für Betriebsräte. In Innovation und Beteiligung in der betrieblichen Praxis: Strategien, Modelle und Erfahrungen in der Umsetzung von Innovationsperspektiven; Nerdinger, F.W., Wilke, P., Röhrig, R., Stracke, S., Eds.; Springer: Wiesbaden, Germany, 2010; pp. 173-188.

120. Blume, L.; Gerstlberger, W. Determinanten betrieblicher Innovation. Partizipation von Beschäftigten als vernachlässigter Einflussfaktor. Ind. Bezieh. 2007, 14, 223-244.

121. Jirjahn, U. Ökonomische Wirkungen der Mitbestimmung in Deutschland. Sozialer Fortschritt 2006, 55, $215-226$.

122. Hall, P.A.; Soskice, D. Varieties of Capitalism. The Institutional Foundations of Comparative Advantage; Oxford University Press: Oxford, UK, 2001.

123. Thomson, S.; Rose, C.; Kronborg, D. Employee representation and board size in nordic countries. Eur. J. Law Econ. 2016, 42, 471-490. [CrossRef]

124. Hermann, C.; Flecker, J. Betriebliche Interessensvertretungen in Österreich. FORBA. 2006. Available online: http://www.forsch ungsnetzwerk.at/downloadpub/betriebliche\%20interessenvertretung.pdf (accessed on 8 August 2019).

125. Rami, U.; Hunger, A. Reden wir über uns und unsere Arbeit: Die Informationstätigkeit des Betriebsrates aus kommunikationstheoretischer und empirischer Sicht. WISO 2011, 34, 113-132. 
126. Krings, T. Die Kommunikation zwischen Betriebsrat und Belegschaft am Beispiel der SFK Österreich AG. 2015. Available online: https://www.jku.at/fileadmin/gruppen/119/WOS/Working_Papers/Abschlussberichte_Forschungspraktika/Absch lussberichtSKF.pdf (accessed on 15 May 2021).

127. Dutton, J.E.; Ashford, S.J.; Wierba, E.E.; O'Neill, R.; Hayes, E. Reading the wind: How middle managers assess the context for issue selling to top management. Strateg. Manag. J. 1997, 15, 407-425. [CrossRef]

128. Milliken, F.J.; Morrison, E.W.; Hewlin, P. An exploratory study of employee silence: What employees do not say to their bosses and why. J. Manag. Stud. 2003, 40, 1453-1476. [CrossRef]

129. Putnam, L.; Nicotera, A.M. Building Theories of Organization; Routledge: New York, NY, USA; London, UK, 2009.

130. Keenan, T. Fables of Responsibility: Aberrations and Predicaments in Ethics and Politics; Stanford University Press: Stanford, CA, USA, 1997.

131. Wallace, R.J. Responsibility and the Moral Sentiments; Harvard University Press: Cambridge, MA, USA, 1994.

132. Putnam, L.; Nicotera, A.M. Communicative Constitution of Organization Is a question: Critical Issues for Addressing It. Manag. Commun. Q. 2010, 42, 158-165. [CrossRef]

133. Taylor, J.R.; Van Every, E.J. The Situated Organization. Case Studies in the Pragmatics of Communication Research; Routledge: New York, NY, USA, 2011.

134. Aaltola, E. Varieties of Empathy and Moral Agency. Topoi 2014, 33, 243-253. [CrossRef]

135. Vincent, N.; van de Poel, I.; van den Hoven, J. Moral Responsibility. Beyond Free Will and Determinism; Springer: Dordrecht, The Netherlands, 2011.

136. Deetz, S.A. Democracy in an Age of Corporate Colonization: Developments in Communication and the Politics of Everyday Life; State University of New York: Albany, NY, USA, 1992.

137. Lange, T. Sustainable HRM and Employee Well-being: An empirical agenda. Int. J. Manpow. 2016, 37, 918-923. [CrossRef]

138. Collins, J. Good to Great: Why Some Companies Make the Leap ... and Others Don't; Harper Collins: New York, NY, USA, 2001.

139. Forster, N. Maximum Performance: A Practical Guide to Leading and Managing People at Work; Edgar Elgar: Cheltenham, UK, 2005.

140. O'Reilly, C.A.; Pfeffer, J. Hidden Value: How Great Companies Achieve Extraordinary Results with Ordinary People; Harvard University Press: Boston, MA, USA, 2000.

141. Stenbacka, C. Qualitative research requires quality concepts of its own. Manag. Decis. 2001, 39, 551-556. [CrossRef]

142. Holliday, A. Doing and Writing Qualitative Research, 2nd ed.; Sage: London, UK, 2008.

143. Lindlof, T.R.; Taylor, B.C. Qualitative Communication Research Methods; Sage: London, UK, 2002.

144. Silverman, D. Interpreting Qualitative Data; Sage: London, UK, 2011.

145. Savin-Baden, M.; Major, C.H. Qualitative Research: The Essential Guide to Theory and Practice; Routledge: New York, NY, USA, 2013.

146. Mayring, P. Qualitative Inhaltsanalyse. Grundlagen und Techniken, 7th ed.; Deutscher Studienverlag: Weinheim, Germany, 2000.

147. Mayring, P. Qualitative Inhaltsanalyse. Grundlagen und Techniken, 8th ed.; Beltz: Weinheim, Germany, 2003. 